\title{
Efektivitas Penerapan Telemental Konseling terhadap Penurunan Kecemasan Remaja Akibat Paparan Informasi Covid 19 di Kota Padang
}

\author{
Windy Freska*, Rika Sarfika, Randy Refnandes \\ Fakultas Keperawatan Universitas Andalas \\ *Corespondece e-mail: windyfreska88@gmail.com
}

\begin{abstract}
Abstrak. Epidemi penyakit Coronavirus 2019 (COVID-19) di Cina adalah ancaman kesehatan global, yang menyebabkan rasa takut, kekhawatiran dalam menerima informasi yang tepat sesuai kebutuhan kesehatan mental di masyarakat. Remaja termasuk pada kelompok yang mengalami dampak psikologis dari Covid 19 yang mengalami kecemasan . Ketidakpastian dari paparan informasi yang berpotensi berdampak negatif pada perkembangan akademik yang mengakibatkan efek buruk pada kesehatan mental remaja. Remaja lebih reseptif terhadap penggunaan aplikasi smartphone, otoritas kesehatan dapat mempertimbangkan untuk menyediakan psikoedukasi dan intervensi psikologis berbasis online atau smartphone Penelitian ini bertujuan untuk mengetahui efektifitas penerapan Telemental Konseling pada remaja kota padang tahun 2020. Desain yang digunakan pada penelitian ini adalah Quasi experimental design dengan pendekatan pre and post with control group design. Teknik pengambilan sampel adalah Simple Random Sampling dengan jumlah sampel sebanyak 44 orang , 22 orang kelompok intervensi dan 22 orang kelompok kontrol . Penelitian ini menggunakan kuisioner Revised Children's Manifest Anxiety Scale (RCMS). Analisa data dilakukan dengan menggunakan Uji Paired T-Test. Hasil dari penelitian ini menunjukan penurunan tingkat kecemasan pada remaja pada kelompok intervensi yaitu dengan rata-rata skor kecemasan sebelum diberikan penerapan Telemental konseling pada kelompok eksperimen adalah 21,18 dan sesudahnya 17,32. Hasil uji statistik ini menunjukan bahwa terdapat pengaruh pemberian Telemental konseling pada kelompok intervensi terhadap penurunan kecemasan pada remaja di Kota Padang. Hasil uji statistik didapatkan nilai $p$-value $=0,000(\mathrm{p}<0,05)$.
\end{abstract}

Kata kunci: Remaja; Kecemasan; Konseling Telemental

\begin{abstract}
The Coronavirus disease 2019 (COVID-19) epidemic in China is a global health threat, which causes fear, anxiety in receiving the right information according to the mental health needs of society. Teenagers are included in the group who experience the psychological impact of Covid 19 who experience anxiety. Adolescents are more receptive to the use of smartphone applications, health authorities may consider providing psychoeducation and online or smartphone-based psychological interventions. This study aims to determine the effectiveness of implementing Telemental Counseling in Padang city adolescents in 2020. The design used in this study was a Quasi experimental design with a pre and post control group design approach. The sampling technique was Simple Random Sampling with a total sample of 44 people, 22 people in the intervention group and 22 from the control group. This study used the Revised Children's Manifest Anxiety Scale (RCMS) questionnaire. Data analysis was performed using Paired T-Test. The results of this study showed a decrease in the level of anxiety in adolescents in the intervention group, namely the average score of anxiety before being given the application of Telemental counseling in the experimental group was 21.18 and 17.32 afterwards. The results of this statistical test show that there is an effect of providing telemental counseling in the intervention group on reducing anxiety in adolescents in Padang City. The statistical test results obtained $p$-value $=0.000(p<0.05)$.
\end{abstract}

Keywords: Teenagers; Anxiety; Telemental Counseling

\section{PENDAHULUAN}

Epidemi penyakit corona virus 2019 (COVID-19) di Cina adalah ancaman kesehatan global, dan sejauh ini merupakan wabah pneumonia atipikal terbesar sejak wabah sindrom pernapasan akut (SARS) parah pada tahun 2003 (Wang, 2020,) Dalam beberapa minggu setelah wabah awal jumlah total kasus dan kematian melebihi SARS. Wabah ini pertama kali terungkap pada akhir Desember 2019 ketika sekelompok kasus pneumonia etiologi yang tidak diketahui ditemukan terkait dengan paparan epidemiologis terkait dengan pasar makanan laut dan eksposur yang tidak dilacak di kota Wuhan, Provinsi Hubei. Sejak itu, jumlah kasus terus meningkat secara eksponensial di dalam dan mendunia termasuk indonesia. Pada hari yang sama, Organisasi Kesehatan Dunia (WHO) menyatakan wabah COVID-19 sebagai masalah kesehatan masyarakat

Epidemi COVID-19 yang sedang berlangsung menyebabkan rasa takut, dan kekhawatiran pada masyarakat dalam menerima informasi yang tepat dan sesuai tentang covid 19 karena hal ini mampu mempengaruhi status kesehatan mental seseorang (Xiang, 2020) . Penelitian sebelumnya telah mengungkapkan dampak psikososial yang mendalam dan luas pada orang di tingkat individu, komunitas, dan internasional selama wabah infeksi. Pada tingkat individu, orang cenderung mengalami rasa takut jatuh sakit atau sekarat, perasaan tidak berdaya, dan stigma 
,dikarenakan ketidakmampuan menyaring informasi yang berkembang begitu cepat penuh dengan spekulasi (Zai, 2020).

Beberapa aplikasi sosial media melakukan penyalahgunaan pada berita utama, mengabadikan stereotip dan prasangka tentang orang Cina karena dianggap sebagai pembawa virus covid 19 yang potensial. Karena itu, Beberapa mahasiswa di cina tersebut beresiko mengalami kejahatan rasial, terutama ketika individu mempertimbangkan mereka menular. Situasi ini bisa menyebabkan masalah kesehatan mental, seperti penyangkalan, stres, kecemasan, dan ketakutan Hal Ini cakupan memicu ketakutan publik, keterasingan,dan diskriminasi. Untuk itu diperlukannya bantuan kebutuhan pengelolaan kesehatan mental pada mahasiswa dicina terkait wabah covid 19 (Yusen, 2020). Mahasiswa indonesia mayoritas berasal dari dibeberapa daerah, sedangkan tempat perkuliahan rata rata berlokasi di daerah pandemi atau kota besar yang menjadi awal dari terjadinya penularan virus covid 19. dan ketika kebijakan pemerintah menyarankan kegiatan work from home ,mahasiswa memutuskan untuk pulang ke kota mereka masing masing hal tersebut membuat beberapa warga resah dengan kedatangan mahasiwa , selain itu perasaan takut dan khawatir berlebihan pada diri merasa menjadi pembawa virus yang berasal dari daerah pandemi. (Huremovic, 2020)

Penyebaran yang cepat dan kebutuhan ekonomi menjadi tinggi yang diakibatkan COVID-19 telah mengekspos kekurangan dari sistem perawatan kesehatan yang besar dan telah menyoroti urgensi memikirkan kembali bagaimana layanan diberikan pemerintah. Langkah-langkah jarak sosial yang dipasangkan dengan realisasi politisi, pembuat kebijakan, dan warga negara akan pentingnya Telehealth dalam konteks pandemi cenderung mengarah pada perubahan signifikan dalam sikap dan perilaku dan menghasilkan adopsi Telehealth dalam skala yang lebih besar dalam jangka panjang. untuk menyambut perubahan sementara yang dibuat untuk meningkatkan akses ke perawatan dan mengatasi efek samping psikologis karantina dan isolasi, dipercaya bahwa beberapa dari perubahan ini harus dibuat permanen. Kedepan, integrasi telehealth, khususnya kesehatan telemental, tidak boleh dilihat sebagai perbaikan sementara pada saat darurat. (Whaibeh, 2020)

Remaja dianggap lebih reseptif terhadap aplikasi smartphone , otoritas kesehatan dapat mempertimbangkan untuk menyediakan psikoedukasi dan intervensi psikologis berbasis online atau smartphone (mis., Terapi perilaku kognitif, CBT) untuk mengurangi risiko penularan virus dengan terapi tatap muka.Secara keseluruhan penggunaan Internet $(93,5 \%)$ adalah saluran informasi kesehatan utama bagi masyarakat umum selama tahap awal epidemi COVID19. Banyak masyarakat (> 90\%) melihat pembaruan rutin mengenai informasi terbaru tentang rute penularan, ketersediaan dan efektivitas obat-obatan / vaksin, saran perjalanan, pengalaman luar negeri dalam menangani COVID-19, jumlah kasus dan lokasi, saran pencegahan, informasi yang lebih khusus (misalnya, untuk orang dengan penyakit kronis), informasi tentang wabah di daerah setempat, dan perincian tentang gejala. Ketika epidemi COVID-19 terus menyebar, beberapa pengembangan strategi dukungan psikologis dan area untuk diprioritaskan dan tempat-tempat lain yang terkena dampak epidemi. Karena epidemi sedang berlangsung, penting untuk menyiapkan sistem perawatan kesehatan dan masyarakat umum agar siap secara medis dan psikologis jika penularan luas terjadi (Patel, 2020).

Telemental kesehatan merupakan metode penyampaian yang efektif untuk mengobati berbagai mental, emosional, perilaku, dan relasional kesehatan masalah. Sementara banyak keterampilan terapeutik yang mengarah ke efektivitas perawatan tatap muka dapat ditransfer, keefektifan kesehatan telemental membutuhkan keterampilan yang unik. Pada sebuah penelitian fenomenologis ditemukan untuk menentukan pengalaman belajar bagaimana menggunakan konferensi video untuk memberikan perawatan kesehatan mentalnyang berfokus pada hubungan . Peserta termasuk 10 lulusan program magister terakreditasi COAMFTE yang menekankan pelatihan kesehatan telemental . Setiap siswa memiliki penempatan praktikum yang memerlukan konferensi video untuk memberikan psikoterapi berbasis hubungan. Analisis data wawancara mengungkapkan ,reservasi pribadi tentang pengiriman jarak jauh; pentingnya perancah pembelajaran siswa melalui kurikulum, pengawasan, dan protokol pengiriman kesehatan mental ,hambatan teknologi yang terkait dengan metode pengiriman ini; dan mengatasi hambatan teknologi melalui intensionalitas (Springer, 2020)

Telemental dapat menjadi solusi ideal untuk mengurangi risiko petugas kesehatan yang memberikan perawatan atau pasien yang terinfeksi terutama dalam pengaturan dengan kekuranganprofesional kesehatan mental. Proposisi nilai Telemental Health adalah dapat secara efektif menanggapi kebutuhan kesehatan mental orang dalam isolasi, karantina, atau mobilitas terbatas sambil mengurangi risiko infeksi pasien dan petugas kesehatan. Dengan demikian, Telemental Health mematuhi jarak sosial, menghindari gangguan perawatan, dan memaksimalkan hasil Kesehatan masyarakat.

\section{METODE}

Desain yang digunakan pada penelitian ini adalah Quasi experimental design dengan pendekatan pre and post with control group design. Teknik pengambilan sampel adalah Simple Random Sampling. Penelitian ini menggunakan kuisioner Revised Children's Manifest Anxiety Scale (RCMS) . Analisa data dilakukan dengan 
menggunakan Uji Paired T-Test.

jumlah sampel sebanyak 44 orang remaja, 22 orang kelompok intervensi dan 22 orang kelompok control. Simple random sampling method was used in the selection of respondent. The inclusion criteria were the following (1) remaja berusia 12 - 19 Tahun (2) berdomisili dikota padang (3) tidak dalam kondisi gangguan mental. Those not mentioned in the inclusion criteria are the exclusion criteria.

Instrumen penelitian menggunakan kuisioner Revised Children's Manifest Anxiety Scale RCMS. Kuesioner ini merupakan kuesioner singkat dengan format yes or no questions yang terdiri dari 37 pertanyaan dengan rincian: 28 pertanyaan yang menggambarkan kecemasan dan 9 pertanyaan untuk mendeteksi kebohongan. Pertanyaan yang menggambarkan kecemasan dapat dikelompokkan menjadi 3 berdasarkan gejala kecemasan yang dialami, yaitu yang menunjukkan gangguan fisik, over sensitifitas dan konsentrasi. Waktu yang dibutuhkan untuk mengisi kuesioner ini adalah 10 menit.

Pada tahapan persiapan peneliti menyiapkan identitas dan organisasi penyelia layanan konseling telemental remaja Fakultas Keperawatan dengan menentukan nama organisasi, struktur tim, tugas pokok fungsi dan peran masing-masing tim konselor. lalu Peneliti mempersiapkan perlengkapan (tools) pelaksanaan konseling telemental berupa pembentukan/pembuatan line telpon yang tersambung pada nomor khusus untuk penangan konseling telemental remaja. Peneliti juga menyediakan media layanan lainnya dengan membentuk layanan group chat dan email pertanyaan dan akses kebutuhan informasi pengurangan kecemasan. Selanjutnya peneliti mengajukan pengurusan uji etik guna memastikan kelayakan etis dari penelitian. Peneliti mengurus surat perizinan dengan memperhatikan instansi maupun sektor yang terlibat dalam penelitian seperti puskesmas, sekolah dan kelurahan. Setelah mendapatkan izin untuk melaksanakan penelitian, Peneliti menyebar google form pada remaja dikota padang dan meminta remaja mengisi kuisioner survei daring melalui platform google form khusus dari peneliti yang berisi set pertanyaan berkaitan dengan tanda gejala kecemasan. didapatkan dari 138 remaja yang mengisi kuisioner dalam google form sebanyak 44 orang yang mengalami kecemasan. Lalu peneliti membagi menjadi 2 kelompok. Kelompok intervensi sebanyak 22 orang kelompok control sebanyak 22 orang. peneliti melakukan sosialisasi layanan konseling telemental kecemasan akibat covid-19 melalui media online seperti facebook, instagram, zoom meeting dan whatasapp group yang merupakan kantungkantung populasi remaja. Peneliti akan menerima panggilan bantuan atau inisiasi obrolan daring dari remaja berdasarkan kriteria yang telah ditentukan yaitu remaja yang memiliki tanda-tanda kecemasan akibat informasi Covid-19. Peneliti melakukan konseling berdasarkan prosedur dan data situasi saat ini yang dialami remaja lalu Peneliti melakukan terminasi konseling dan meminta remaja untuk mengisi kuisioner daring tentang respon kecemasan pasca konseling telemental untuk kegiatan post test.

Data tentang tingkat kecemasan didiperoleh dari kuisioner Revised Children's Manifest Anxiety Scale (RCMAS) Kuesioner ini merupakan kuesioner singkat dengan format yes or no questions yang terdiri dari 37 pertanyaan dengan rincian: 28 pertanyaan yang menggambarkan kecemasan dan 9 pertanyaan untuk mendeteksi kebohongan. Pertanyaan yang menggambarkan kecemasan dapat dikelompokkan menjadi 3 berdasarkan gejala kecemasan yang dialami, yaitu yang menunjukkan gangguan fisik, over sensitifitas dan konsentrasi Skoring kecemasan pada kuesioner ini berdasarkan jumlah jawaban ya pada 28 pertanyaan mengenai kecemasan, sehingga skornya adalah $0-28$ poin dan dengan skor $>19$ poin maka responden dinyatakan mengalami kecemasan yang signifikan secara klinis. Analisa data dilakukan dengan menggunakan Uji Paired T-Test.

\section{HASIL DAN PEMBAHASAN}

Penelitian ini dilakukan pada remaja di Kota Padang. Pengumpulan data dilakukan pada bulan Mei sampai bulan Oktoberr 2020. Didapatkan jumlah populasi sebanyak 138 orang dengan jumlah sampel sebanyak 44 orang, peneliti menggunakan teknik simple random sampling. Setelah didapatkan jumlah sampelnya, peneliti membagi menjadi dua kelompok. Kelompok pertama yaitu kelompok eksperimen yang diberikan intervensi telemental health dan kelompok kedua yaitu kelompok kontrol.

Tabel 1. Distribusi Frekuensi Umur dan Jenis Kelamin Responden Kelompok Eksperimen

\begin{tabular}{ccc}
\hline $\begin{array}{c}\text { Karakteristik } \\
\text { Responden }\end{array}$ & $\begin{array}{c}\text { Frekuensi } \\
\text { (orang) }\end{array}$ & $\begin{array}{c}\text { Persentase } \\
(\boldsymbol{\%})\end{array}$ \\
\hline Umur (tahun) & 1 & \\
13 & 3 & 4,5 \\
15 & 8 & 13,6 \\
16 & 5 & 36,4 \\
17 & 3 & 22,7 \\
18 & 2 & 13,6 \\
19 & & 9,1 \\
Jenis Kelamin & 3 & 13,6 \\
Laki-laki & 19 & 86,4 \\
Perempuan & &
\end{tabular}

Sumber: Data diolah

Berdasarkan tabel 1, diketahui bahwa distribusi frekuensi umur responden kelompok eksperimen paling banyak pada umur 16 tahun yaitu sebanyak 8 orang $(36,4 \%)$. Diketahui bahwa distribusi frekuensi responden kelompok eksperimen yang berjenis kelamin laki-laki sebanyak 3 orang $(23,6 \%)$ dan berjenis kelamin perempuan sebanyak 19 orang $(86,4 \%)$. 
Windy Freska, Rika Sarfika dan Randy Refnandes, Efektivitas Penerapan Telemental Konseling terhadap Penurunan Kecemasan Remaja Akibat Paparan Informasi Covid 19 di Kota Padang

Tabel 2. Distribusi Frekuensi Umur dan JenisKelamin Responden Kelompok Kontrol

\begin{tabular}{ccc}
\hline $\begin{array}{c}\text { Karakteristik } \\
\text { Responden }\end{array}$ & $\begin{array}{c}\text { Frekuensi } \\
\text { (orang) }\end{array}$ & $\begin{array}{c}\text { Persentase } \\
(\%)\end{array}$ \\
\hline Umur (tahun) & 2 & \\
14 & 3 & 9,1 \\
15 & 5 & 13,6 \\
16 & 5 & 22,7 \\
17 & 7 & 22,7 \\
19 & & 31,8 \\
Jenis Kelamin & 4 & \\
Laki-laki & 18 & 18,2 \\
Perempuan & & 81,8 \\
\hline
\end{tabular}

Sumber: Data diolah

Berdasarkan tabel 2, diketahui bahwa distribusi frekuensi umur responden kelompok eksperimen paling banyak pada umur 19 tahun yaitu sebanyak 7 orang $(31,8 \%)$. Diketahui bahwa distribusi frekuensi responden kelompok eksperimen yang berjenis kelamin laki-laki sebanyak 4 orang $(18,2 \%)$ dan berjenis kelamin perempuan sebanyak 18 orang $(81,8 \%)$.

Tabel 3. Kecemasan Responden Sebelum dan Sesudah Kelompok Eksperimen

\begin{tabular}{lllll}
\hline Kelompok Eksperimen & Mean & SD & Min & Max \\
\hline Pre-Test & 21,18 & 1,893 & 20 & 28 \\
Post-Test & 17,32 & 1,359 & 15 & 19 \\
\hline
\end{tabular}

Sumber: Data diolah

Berdasarkan table 3 dapat diketahui bahwa dari 22 orang responden kelompok eksperimen sebelum diberikan konseling telemental health memiliki rata-rata kecemasan 21,18 dengan standar deviasi 1,893 serta nilai minimum 20 dan nilai maksimum 28. Sesudah diberikan Telemental Konseling memiliki rata-rata kecemasan 17,32 dengan standar deviasi 1,359 serta nilai minimum 15 dan nilai maksimum 19.

Tabel 4. Kecemasan Responden Sebelum dan Sesudah Kelompok Kontrol

\begin{tabular}{ccccc}
\hline Kelompok Kontrol & Mean & SD & Min & Max \\
\hline Pre-Test & 21,18 & 2,281 & 20 & 28 \\
Post-Test & 19,68 & 1,555 & 16 & 22 \\
\hline
\end{tabular}

Sumber: Data diolah

Berdasarkan table 4 dapat diketahui bahwa dari 22 orang responden kelompok control sebelumnya memiliki rata-rata kecemasan 21,18 dengan standar deviasi 2,281 serta nilai minimum 20 dan nilai maksimum 28. Sesudah dilakukan pengontrolan kecemasan memiliki rata-rata kecemasan 19,68 dengan standar deviasi 1,555 serta nilai minimum 16 dan nilai maksimum 22

Tabel 5 Pengaruh Telemental Health terhadap Kecemasan Responden Sebelum dan Sesudah Kelompok Eksperimen

\begin{tabular}{lcll}
\hline Kelompok & \multirow{2}{*}{ Mean } & \multicolumn{2}{l}{ Difference } \\
\cline { 3 - 4 } Eksperimen & & Selisih Mean & p-value \\
\hline Pre-Test & 21,18 & 3,864 & 0,000 \\
Post-Test & 17,32 & & \\
\hline
\end{tabular}

Sumber: Data diolah
Tabel 5 menunjukkan bahwa rata-rata skor kecemasan sebelum diberikan telemental health pada kelompok eksperimen adalah 21,18 dan sesudahnya 17,32. Dengan demikian didapatkan selisih mean sebelum dan sesudah diberikan telemental health adalah 3,864. Hasil uji statistik didapatkan nilai $p$-value $=0,000$ $(\mathrm{p}<0,05)$. Hasil uji statistic ini berarti terdapat pengaruh pemberian telemental health pada kelompok eksperimen terhadap penurunan kecemasan pada remaja di Kota Padang.

Tabel 6. Pengaruh Telemental Health terhadap Kecemasan Responden Sebelum dan Sesudah Kelompok Kontrol

\begin{tabular}{cccc}
\hline \multirow{2}{*}{ Kelompok Kontrol } & \multirow{2}{*}{ Mean } & \multicolumn{2}{c}{ Difference } \\
\cline { 3 - 4 } & & Selisih Mean & p-value \\
\hline Pre-Test & 21,18 & \multirow{2}{*}{1,500} & 0,004 \\
Post-Test & 19,68 & & \\
\hline
\end{tabular}

Sumber: Data diolah

Tabel 6 menunjukkan bahwa rata-rata skor kecemasan sebelum diberikan telemental health konseling pada kelompok kontrol adalah 21,18 dan sesudahnya 19,68. Dengan demikian didapatkan selisih mean sebelum dan sesudah diberikan telemental health adalah 1,500. Hasil uji statistik didapatkan nilai $p$-value $=0,004(\mathrm{p}<0,05)$. Hasil uji statistik ini berarti terdapat pengaruh pemberian telemental health pada kelompok control terhadap penurunan kecemasan pada remaja di Kota Padang.

Hasil uji statistik didapatkan nilai $p$-value $=0,000$ ( $\mathrm{p}<0,05)$. Hasil uji statistic ini berarti terdapat pengaruh pemberian Telemental Konseling pada kelompok eksperimen terhadap penurunan kecemasan pada remaja di Kota Padang. Sebagian besar penelitian tentang layanan telekonferensi menunjukkan bahwa keefektifan sebanding dengan layanan tatap muka di seluruh gangguan termasuk depresi, gangguan stres pasca trauma, dan gangguan kecemasan (Ralston, 2019). Cina cukup berhasil dengan pendekatan ini. Para peneliti baru-baru ini menulis dalam Lancet Commentary bahwa selama wabah terburuk pada bulan Januari, Tiongkok berhasil memberikan konseling psikologis online dan bantuan mandiri secara luas diluncurkan oleh para profesional kesehatan mental di institusi medis, universitas, dan perkumpulan akademik (Liu, 2020)

Di AS, pandemi juga menjadi katalisator cepatnya adopsi telehealth .Medicare sekarang memungkinkan penagihan untuk telehealth. Lebih lanjut, UndangUndang Portabilitas dan Akuntabilitas Asuransi Kesehatan (HIPAA) telah ditinjau kembali untuk mengizinkan lebih banyak penyedia medis menggunakan platform yang sesuai dengan HIPAA untuk berkomunikasi dengan pasien. Hal ini menghilangkan hambatan utama untuk adopsi telemedicine yang lebih luas dan juga dapat memberikan kesempatan yang luar biasa bagi pasien yang 
Windy Freska, Rika Sarfika dan Randy Refnandes, Efektivitas Penerapan Telemental Konseling terhadap Penurunan Kecemasan Remaja Akibat Paparan Informasi Covid 19 di Kota Padang

sebelumnya merasa tidak nyaman mencari perawatan kesehatan mental untuk sekarang mendekati layanan ini.

Selain aplikasi, platform pesan teks dapat dimanfaatkan untuk membantu orang mengatasi tantangan kesehatan mental yang ditimbulkan oleh COVID-19. Karena teks juga dikirimkan melalui perangkat individu, maka teks mudah diberikan kepada banyak orang sekaligus menggunakan platform pesan teks otomatis. Intervensi pesan teks telah menunjukkan efektivitas dalam promosi kesehatan perilaku dan manajemen penyakit . pesan teks sebagai alat yang tepat untuk populasi yang minim terpapar digital dan kelompok yang kurang jauh dari usat pelayanan kesehatan. Misalnya, platform SMS kami yang disetujui HIPAA, SMS Sehat, dikembangkan dengan dan untuk populasi berpenghasilan rendah dan menunjukkan penerimaan yang tinggi pada populasi yang kurang terlayani . baru-baru ini beberapa studi meluncurkan perpesanan teks untuk memberikan dukungan berskala luas kepada individu-individu yang tertarik di Amerika Serikat melalui pesan teks otomatis harian, yang berisi kiat-kiat untuk mengatasi jarak sosial dan kecemasan COVID-19.

Media sosial memainkan peran yang rumit dalam pengelolaan kesehatan mental. Di satu sisi, ini dapat memberikan koneksi yang positif dan mendukung selama masa isolasi fisik. Pekerjaan sebelumnya menunjukkan bahwa banyak orang dengan penyakit mental semakin beralih ke media sosial untuk berbagi pengalaman dan mencari informasi serta nasihat kesehatan mental (Naslund, 2019)

Media sosial telah memainkan peran besar dalam penyebaran informasi sejak dimulainya wabah COVID19, termasuk informasi yang salah dan "berita palsu". Platform media sosial besar sekarang dilaporkan mengambil langkah untuk menghapus konten palsu atau teori konspirasi tentang pandemi, menggunakan kecerdasan buatan (AI); dan mendistribusikan informasi yang dapat diandalkan, seperti yang dikembangkan oleh Organisasi Kesehatan Dunia (Lawfare, 2020)

Telemental konseling memiliki Peranan penting dalam penggunaan perangkat lunak telekonferensi untuk sesi terapi selama pandemi COVID-19. Data terbaru dari klinik perawatan primer menunjukkan bahwa, meskipun konsultasi perawatan video naik $80 \%$ pada akhir Maret dan awal April, kelompok minoritas mewakili porsi yang lebih kecil dari kunjungan ini (Naori, 2020). Ini sebagian karena kurangnya ketersediaan Internet, yang bervariasi karena paket data yang terbatas dan kurangnya $\mathrm{Wi}-\mathrm{Fi}$, serta ketidakmampuan untuk menggunakan fitur ponsel cerdas seperti mengunduh aplikasi. Saat ini, beberapa penyedia telekomunikasi Amerika Serikat menawarkan layanan Internet gratis (The New York Times, 2020). Namun, strategi jangka panjang perlu dikembangkan untuk mencegah semakin meluasnya kesenjangan digital , termasuk menyediakan akses Internet berkecepatan tinggi yang terjangkau, meningkatkan kegunaan program telehealth, dan memberikan panduan / pelatihan yang sesuai untuk pasien yang menggunakan layanan ini.

\section{SIMPULAN}

Epidemi COVID-19 terus menyebar, beberapa pengembangan strategi dukungan psikologis dan area untuk diprioritaskan dan tempat-tempat lain yang terkena dampak epidemi . Krisis kesehatan akut menuntut peningkatan sumber daya kesehatan mental. masyarakat membutuhkan Penanganan kebutuhan fisik dan mental yang mudah dan efisien. Telehealth dalam konteks pandemi cenderung mengarah pada perubahan signifikan dalam sikap dan perilaku dan menghasilkan adopsi Telehealth dalam skala yang lebih besar dalam jangka panjang. untuk menyambut perubahan sementara yang dibuat untuk meningkatkan akses ke perawatan dan mengatasi efek samping psikologis karantina dan isolasi, dipercaya bahwa beberapa dari perubahan ini harus dibuat permanen. Kedepan, integrasi telehealth, khususnya kesehatan telemental, tidak boleh dilihat sebagai perbaikan sementara pada saat darurat.

\section{DAFTAR PUSTAKA}

Huremovic D.(2020)A mental health response to infection outbreak. Cham: Springer International Publishing

Lawfare, Vander Stoep A, Zhou C, McCarty CA, Katon W (2020) . Effectiveness of a Telehealth Service Delivery Model for Treating AttentionDeficit/Hyperactivity Disorder: A CommunityBased Randomized Controlled Trial. Journal of the American Academy of Child \& Adolescent Psychiatry. 2015;54

Liu, Gold WL, Robinson S, Pogorski S, Galea S, Styra R (2020). SARS control and psychological effects of quarantine, Toronto, Canada. Emerg Infect Dis. ;10(7):1206-1212

Naori JH. (2020) Telepsychiatry: videoconferencing in the delivery of psychiatric care. $A m \quad J$ Psychiatry. ;170(3):256-262.

Naslund, G.J.; Potts, H.W.W.; Michie, S.(2019) The impact of communications about swine flu (influenza A H1N1v) on public responses to the outbreak: Results from 36 national telephone surveys in the UK. Health Technol. Assess. 14, $183-266$

Patel, A.; Jernigan, D.B. Initial Public Health Response and Interim Clinical Guidance for the 2019 Novel Coronavirus Outbreak-United States, 31 December 2019-4 February 2020. MMWR Morb.Mortal. Wkly. Rep. , 69, 140-146

Ralston (2019). Free from stres (panduan mengatasi stres). Jakarta : Kelompok Gramedia; 2003. Halaman 11.

Springer $\mathrm{P}^{1}$, Bischoff $\mathrm{RJ}^{1}$, Kohel $\mathrm{K}^{1}$, Taylor $\mathrm{NC}^{2}$, Farero $\mathrm{A}^{3}$.J Marital Fam Ther. 2020 Apr;46(2):201-217. doi: 10.1111/jmft.12431. Epub 2020 Apr 
Windy Freska, Rika Sarfika dan Randy Refnandes, Efektivitas Penerapan Telemental Konseling terhadap Penurunan Kecemasan Remaja Akibat Paparan Informasi Covid 19 di Kota Padang

11.Collaborative Care at a Distance: Student

Therapists' Experiences of Learning and

Delivering Relationally

Focused Telemental Health.

The New York Times. (2020) Director-General's opening remarks at the media briefing on COVID19 - 11 March 2. 2020.

Wang, C. (2020) A novel coronavirus outbreakofglobalhealthconcern. Lancet, 395 , 470-473

Whaibeh E, Mahmoud H, Naal $\mathrm{H}$.Telemental Health in the Context of a Pandemic: the COVID-19 Experience.2020. https://www.ncbi.nlm.nih.gov/pubmed/32292687.

Xiang, Y.-T. Timely mental health care for the 2019 novel coronavirus outbreak is urgently needed. Lancet Psychiatry 2020, 7, 228-229.

Yusen, (2020) novel corona virus for adolescents, Health Care Off. J. Eur. Soc. Eng. Med. , 22, 847859.

Zai ,(2020) : Effectiveness of a Telehealth Journal of the American Academy of Child \& Adolescent Psychiatry. 675;54 